\title{
EPISTEMIC AUTHORITY, PRE-EMPTION, AND NORMATIVE POWER
}

\author{
BENJAMIN MCMYLER
}

Texas A\&M University

\section{INTRODUCTION ${ }^{1}$}

Linda Zagzebski's Epistemic Authority is an expansive book, exploring a range of issues from the nature of the self, agency, and trust, to the problems of epistemic circularity and peer disagreement. The heart of the book, however, that which ties all of these disparate topics together, is an exploration and defence of the idea that there is such a thing as genuinely epistemic authority, a kind of authority over belief that genuinely parallels practical authority, or authority over action. Insofar as the topic of authority is a central concern of social and political philosophers, it is surprising that this topic has received relatively little attention from social epistemologists. Zagzebski's book goes a long way towards rectifying this situation, and as such it will undoubtedly serve as a touchstone for future work.

Zagzebski's account of epistemic authority is formulated so as to parallel what can safely be called the standard contemporary account of practical authority, Joseph Raz's service conception of authority. ${ }^{2}$ According to Raz, practical authorities perform the service of mediating between agents and the reasons for action that apply to them. Authorities perform this service by issuing directives, such as laws, orders, or commands, that provide agents with reasons for action that are supposed to both reflect and replace the reasons for action that apply to these agents independent of the directive. Raz calls such reasons for action 'pre-emptive' reasons. The notion of pre-emption is supposed to explain the intuitive respect in which practical authorities purport to be in a position to settle for us the

\footnotetext{
${ }^{1}$ I am indebted to Linda Zagzebski for many discussions of this material, as well as to the comments of an anonymous referee.

2 The canonical statement of this position is $\operatorname{Raz}(1986)$.
} 
question what to do. For Raz, authorities settle practical questions for us by giving us pre-emptive reasons for action.

Following Raz, Zagzebski states that what is essential to authority is the normative power to generate pre-emptive reasons, and she holds that such normative powers can be powers to generate pre-emptive reasons for belief just as much as for action.

What is essential to authority is that it is a normative power that generates reasons for others to do or believe something preemptively ... A preemptive reason is a reason that replaces other reasons the subject has. Believing what another person believes or tells me preemptively is parallel to doing what he tells me to do preemptively. In both cases what the authority does gives me reason to believe or do something that replaces my other reasons relevant to the belief or act. (Zagzebski 2012: 102$)^{3}$

Raz himself seems to accept that there can be epistemic authority that meets the general conditions of his service conception. In a recent paper he writes:

Just as with any practical authority, the point of theoretical authority is to enable me to conform to reason, this time reason for belief, better than I would otherwise be able to do. This requires taking the expert advice and allowing it to pre-empt my own assessment of the evidence. If I do not do that, I do not benefit from it. (Raz 2009: 155)

Raz here claims that 'expert advice' can provide pre-emptive reasons for belief. I take it that what Raz calls expert advice is what epistemologists would call expert testimony, for example, a climate scientist's telling me that global warming is occurring and is largely the result of human activity. Raz is claiming that such testimony can provide pre-emptive reasons for belief and that agents like the climate scientist thus amount to epistemic (or theoretical) authorities.

Interestingly, however, Zagzebski's initial cases of epistemic authority are not cases of expert or authoritative testimony. Zagzebski's initial defence of epistemic authority in Chapter 5 of her book concerns the authority of belief, not testimony. It concerns cases in which I trust the way in which someone else gets her belief in a particular domain more that I trust the way in which I would get the belief myself. As she puts it,

${ }^{3}$ In a similar vein, Lawlor (2013) argues that the speech act of assurance purports to provide hearers with exclusionary or pre-emptive reasons for belief. I argue for a similar parallel between testimony and authoritative practical directives in McMyler (2011). 
'In cases of these kinds the conscientious thing to do is to let the other person stand in for me in my attempt to get the truth in that domain and to adopt his belief. This in broad outline is what I mean by epistemic authority.' (2012: 105) Zagzebski notes that this is not the most natural parallel to the case of practical authority. She claims that the authority of testimony, the topic of Chapter 6, is a stronger form of authority that more closely resembles authority over action (2012: 119). Nevertheless, she thinks that the authority of belief bears sufficient resemblance to practical authority for it to count as a genuine form of authority. Zagzebski thus proposes that there are two general types of epistemic authority, the authority of belief and the authority of testimony, both of which deserve to be characterized as forms of authority in virtue of their being normative powers to generate for others pre-emptive reasons for belief.

I think that Zagzebski is right that there is such a thing as epistemic authority, where this is understood as a kind of authority over belief that robustly parallels authority over action. With this much agreement in mind, however, I want to raise three worries concerning the details of Zagzebski's account, all of which bear on her central contention that epistemic authority is a normative power to generate pre-emptive reasons for belief. First, it is difficult to see how Zagzebski's account of the authority of belief meets the conditions that Raz proposes on the possession of a normative power. If authority is a normative power over others, and if we accept Raz's conception of the nature of normative powers, then it is difficult to see how there can be such a thing as the authority of belief. This is not a problem for Zagzebski's account of the authority of testimony. However, second, if we accept Raz's conception of the nature of pre-emptive reasons, it is difficult to see how there can be such a thing as a pre-emptive reason for belief. Raz holds that preemptive reasons are a species of what he calls 'second-order reasons', but given the nature of second-order reasons, I don't see how there can be reasons that are epistemically second-order. This is a problem for both Zagzebski's account of the authority of testimony and her account of the authority of belief. Finally, third, even if we can make sense of the notion of pre-emptive epistemic reasons, it isn't clear that the normative power to give pre-emptive reasons is actually sufficient for authority. This is a problem for the Razian framework for understanding authority in general, be it epistemic or practical. I end on a positive note, suggesting that Zagzebski's discussion of the authority of testimony points to 
considerations that take us beyond the official Razian framework for understanding authority, considerations that might be employed to address the second and third problems outlined here.

\section{BELIEF AND NORMATIVE POWER}

As I have said, Zagzebski's initial defence of epistemic authority in Chapter 5 concerns the authority of belief. Generally speaking, another's belief is authoritative for me when I conscientiously trust the way in which the other gets her belief more than I would the way in which I would get my own belief were I to attempt to determine what to believe myself. In such cases, Zagzebski claims that the reasonable thing to do is to let the authority 'stand in for me' in determining what to believe, and I do this by allowing the authority's judgment to pre-empt my own. She formulates this in terms of the following pre-emption thesis for epistemic authority:

The fact that the authority has a belief $\mathrm{p}$ is a reason for me to believe $\mathrm{p}$ that replaces my other reasons relevant to believing $\mathrm{p}$ and is not simply added to them. (2012: 107)

Zagzebski is aware that this does not directly parallel Raz's account of practical authority, but I think it is worth pausing a moment to see why. Consider in this respect what a parallel pre-emption thesis for practical authority might look like:

The fact that the authority $\Phi$ s (or intends to $\Phi$ ) is a reason for me to $\Phi$ (or intend to $\Phi$ ) that replaces my other reasons relevant to $\Phi$-ing (or intending to $\Phi$ ) and is not simply added to them.

This is not Raz's pre-emption thesis. Raz's pre-emption thesis for practical authority is instead something like the following:

The fact that an authority directs (commands, orders, tells) me to $\Phi$ is a reason for me to $\Phi$ that replaces my other reasons relevant to $\Phi$-ing and is not simply added to them. ${ }^{4}$

${ }^{4} \mathrm{Raz}$ writes, 'One thesis I am arguing for claims that authoritative reasons are preemptive: the fact that an authority requires performance of an action is a reason for its performance which is not to be added to all other relevant reasons when assessing what to do, but should exclude and take the place of some of them.' (1986: 46) I have formulated the pre-emption thesis in the text in the first-person in order to parallel Zagzebski's preemption thesis. Note that on Raz's formulation, the notion of an authority's 'requiring performance, or as I put it above, directing me to $\Phi$, is integral to the account. 
Raz holds that practical authority is a matter of the way in which the directives of authorities are capable of providing pre-emptive reasons for action. Zagzebski's pre-emption thesis for epistemic authority does not require the issuing of directives, and as a result, I doubt that it amounts to something that is rightly referred to as a kind of authority.

Note that the practical parallel of Zagzebski's pre-emption thesis does not characterize cases of practical authority. I might very well treat someone that I admire as an exemplar concerning which actions to perform in a given domain without thereby treating her as a practical authority. For example, I might seek to emulate my neighbour's gardening techniques, or the intentions involved therein, without thereby treating my neighbour as having any practical authority over me. In emulating my neighbour, I am not obeying her, and this is because she hasn't told me to do anything. So if the practical parallel of Zagzebski's pre-emption thesis doesn't characterize cases of practical authority, why should we think that the epistemic version characterizes something that deserves to be called authority?

One might suggest that epistemic and practical authority simply differ in this regard. I take it that this is roughly Zagzebski's view. Along these lines, one might suggest that in seeking to emulate my neighbour's gardening techniques I am in fact treating her as an epistemic authority. After all, her actions express her beliefs about what is to be done gardening-wise, and if I conscientiously trust those beliefs more than I would my own beliefs were I to attempt to determine what to do for myself, then I might treat the beliefs that are expressed in her actions as pre-emptive reasons for belief. Zagzebski herself describes a case very much like this as a case of epistemic authority: 'I may want to attend a lecture but might not be sure where the lecture room is. I may then follow a group of people whom I know are going to the lecture. I assume that their behaviour indicates their belief about the location of the room, and when I do so, it is their belief that I take to be authoritative.' (2012: 120)

I think there is reason to resist construing such cases as cases of genuine authority. Recall that Zagzebski accepts Raz's conception of authority as a normative power to generate for others pre-emptive reasons. As she recognizes, having what one says or does treated as a preemptive reason is insufficient for possession of such a normative power. Immediately after introducing Raz's account of authority as normative power, she writes: 
I am not suggesting that taking a reason to be preemptive is sufficient for either acting or believing on authority. If you love someone, you might take the fact that he or she asks you to do something as a preemptive reason to do it, but when you do so you are not treating the beloved as an authority. Similarly, it is possible (although less likely), that you will take the fact that the loved one has a certain belief as a preemptive reason to believe it. If so, believing preemptively is not sufficient for believing on authority. We usually do not think that the people we love have a normative power to give us preemptive reasons just because we love them, even if we choose to take their wishes as giving us preemptive reasons. In contrast, authority is such a power. (Zagzebski 2012: 102-103)

Zagzebski here claims that we might rationally or justifiably treat a loved one's request (or belief) as a pre-emptive reason for action (or belief) without this making the loved one a practical (or epistemic) authority. Treating what another does or believes pre-emptively is insufficient for the person's possessing a normative power to generate pre-emptive reasons for others. What more, then, is required for possession of such a normative power?

In Practical Reason and Norms, Raz gives the following definition of normative power:

An act is the exercise of a normative power if, and only if, it is recognized as effecting a normative change because, among other possible justifications, it is an act of a type that, if recognized as effecting a normative change, acts of this type will be generally performed only if the persons concerned want to secure this normative change. (Raz 1999: 103$)^{5}$

There are two things to note about this definition. First, this definition presupposes that the exercise of a normative power is an act, an intentional action. For Raz, to exercise the normative power to give pre-emptive reasons is, paradigmatically, to order, command, or legislate that someone do something. No such actions are present in the case of my neighbour or Zagzebski's pedestrians. My neighbour has not directed me to do or believe anything, and neither have the pedestrians in Zagzebski’s example.

But perhaps Raz's definition needs to be modified in order to make room for epistemic authority. Perhaps another person's believing that

\footnotetext{
${ }^{5}$ See also Raz (1979: 18).
} 
$\mathrm{p}$ in a way that is conscientiously recognized by me as being more conscientious than would be my own belief were I to try to form the belief myself is sufficient for possessing the relevant normative epistemic power. We might thus try to modify Raz's definition of normative power by replacing talk of acts and performing actions with talk of beliefs and holding beliefs:

A belief is the exercise of a normative power if, and only if, it is recognized as effecting a normative change because, among other possible justifications, it is a belief of a type that, if recognized as effecting a normative change, beliefs of this type will generally be held only if the persons concerned want to secure this normative change.

Second, however, not only does Raz's definition of normative power presume that exercises of normative powers are intentional actions, it also holds that these actions must be of a type that are typically performed in order to secure a normative change, in the case of authority, in order to give to or generate for others pre-emptive reasons. Orders and commands are speech acts that are issued with the intention of giving or generating pre-emptive reasons. This is what distinguishes such exercises of normative power from other speech acts, like requests, that might be rationally treated as providing pre-emptive reasons but that are not issued with the intention of doing so. Neither my neighbour's gardening beliefs nor the pedestrian's beliefs concerning the location of the lecture are held in order to generate pre-emptive reasons for others. In fact, it is unclear what it could even mean to hold a belief in order to secure a normative change. The attitude of belief looks like the wrong kind of thing to be the exercise of a normative power, and so believing that $\mathrm{p}$, even though it might be rationally treated as providing pre-emptive reasons, cannot itself be an exercise of authority.

One might object that Raz himself claims that the intention to secure a normative change is not necessary for exercising a normative power.

Normally only acts done with the intention of producing relevant normative change are recognized as producing it. But this is not always the case, and there are many exceptions particularly in the law or other institutionalized normative systems. One may make a binding contract without realizing that one did, for example. For this reason, the definition [of normative power] turns, not on the intentions with which the act is performed, but rather on the reasons for regarding it as effecting a normative change. (Raz 1999: 104) 
If I understand him, what Raz is here claiming is that the exercise of a normative power should be understood not in terms of the intentions of the person or institution exercising the power on the particular occasion but rather in terms of what justifies us in taking what the person or institution does to be an exercise of such a power. On the surface, this sounds congenial to Zagzebski's position. After all, she offers several epistemic parallels to Raz's Normal Justification Thesis showing that epistemic authority can be justified for us in much the same way as practical authority. Raz's Normal Justification Thesis states that 'the normal way to establish that a person has authority over another person involves showing that the alleged subject is likely better to comply with reasons which apply to him (other than the alleged authoritative directives) if he accepts the directives of the alleged authority as authoritatively binding and tries to follow them, rather than by trying to follow the reasons which apply to him directly' (Raz 1986: 53). Zagzebski offers two parallel justification theses for the authority of belief, the second of which states that 'the authority of another person's belief for me is justified by my conscientious judgment that I am more likely to form a belief that survives my conscientious self-reflection if I believe what the authority believes than if I try to figure out what to believe myself' (Zagzebski 2012: 110-111). As I understand it, however, Raz's Normal Justification Thesis simply assumes that we have in view an attempted exercise of a normative power, an attempt to give pre-emptive reasons. The question that the Normal Justification Thesis is meant to answer is the question of what makes such an attempt successful, one that succeeds in giving the kind of reason that it purports to give. ${ }^{6}$ It is an account of what makes an authority legitimate. The Normal Justification Thesis does not answer the question of what justifies us in taking something to be an attempted exercise of a normative power. Raz's answer to this question lies in his definition of normative power. We are justified in taking something to be an attempted exercise of a normative power only if it is an act of a type that, if recognized as effecting a normative change, acts of this type will be generally performed only if the persons concerned want to secure this normative change.

In this respect, the reason that one can make a binding contract without realizing it or intending to do so is that one can perform actions, such as signing a document, that are of a type that, if recognized

${ }^{6}$ See, for example, Raz (1986: 53). 
as effecting a normative change, acts of this type will be generally performed only if the persons concerned intend to so bind themselves. So while a particular person's intending to secure a normative change isn't necessary for the exercise of a normative power on a particular occasion, for such an exercise to count as such it must be of a type that is recognized as being generally performed only if the persons involved want to secure this change. Beliefs are simply not of this type. So while we might have good reason to treat the beliefs of others as pre-emptive reasons for belief, particularly when Zagzebski's Justification Theses for the Authority of Belief are satisfied, if authority is a normative power to generate pre-emptive reasons for others, it looks like there can be no authority of belief.

\section{PRE-EMPTIVE REASONS FOR BELIEF}

This problem concerning the notion of normative power does not tell against Zagzebski's account in Chapter 6 of the authority of testimony. In contrast to the case of the authority of belief, we can easily formulate a pre-emption thesis for the authority of testimony that parallels Raz's pre-emption thesis for practical authority:

The fact that an authority tells me that $\mathrm{p}$ is a reason for me to believe that $p$ that replaces my other reasons relevant to believing that $p$ and is not simply added to them.

Just as telling an audience to $\Phi$ is a speech act that purports to give the audience a pre-emptive reason to $\Phi$, so telling an audience that $\mathrm{p}$ can be construed as a speech act that purports to give the audience a preemptive reason to believe that $\mathrm{p}$. If the case of my neighbour is modified such that it involves her telling me that such and such is the thing to do in my garden, and if Zagzebski's case of the pedestrians is modified such that it involves their telling me the location of the lecture, then it seems much more plausible that we have in view cases in which I might believe these things on the authority of the relevant speakers. In telling me that such and such is the case, the relevant speakers can be construed as performing actions that satisfy Raz's conditions on the exercise of a normative power, actions of a type that, if recognized as effecting a normative change, acts of this type will be generally performed only if the persons concerned want to secure this normative change. And as we 
have seen, Raz himself seems to accept that such authoritative testimony can meet the general conditions of his service conception of authority.

Still, I would like to raise a further problem for this account, one concerning the notion of pre-emption itself. Raz provides a fairly detailed account of the nature of pre-emptive reasons, and I worry that these details make it difficult to see how there can be such a thing as a pre-emptive epistemic reason.

For Raz, pre-emptive reasons are a species of what he calls secondorder reasons. The point of introducing this category of second-order reasons is to illuminate differences in the kinds of conflict that can arise between reasons. While first-order reasons can defeat and outweigh one another, Raz holds that second-order reasons interact with other reasons in a quite different way. Second-order reasons are reasons to act for firstorder reasons or to refrain from acting for first-order reasons (1999: 39). Second-order reasons do not affect the strength of first-order reasons. Rather, they determine whether certain first-order reasons are to be acted upon, and as such they cannot be simply added to the balance of first-order reasons. This is what it means to say that second-order reasons replace other reasons. Raz calls negative second-order reasons, reasons for refraining from acting for certain first-order reasons, exclusionary or pre-emptive reasons. Pre-emptive reasons serve to exclude or pre-empt other reasons by being reasons for not acting for these other reasons.

In addition to their pre-emptive nature, the reasons for action provided by authoritative directives are themselves first-order reasons for performing the root action. An authority's ordering me to $\Phi$ is for me both a first-order reason to $\Phi$ and a second-order reason not to act for certain other conflicting reasons. In this respect, the pre-emptive nature of an authoritative directive serves to 'protect' the first-order reason provided by the directive itself. Raz calls reasons that are both first-order reasons and second-order exclusionary or pre-emptive reasons protected reasons (1979: 18).

Second-order reasons are not simply reasons for performing or refraining from performing the root action. If they were, then they wouldn't be adequately distinguished from first-order reasons. What makes second-order reasons second-order is that they are reasons for performing a kind of higher-order action, the action of acting for a reason or intentionally refraining from acting for a reason.

There is one important point to bear in mind concerning second-order reasons: They are reasons for action, the actions concerned being acting 
for a reason and not acting for a reason. If $P$ is a reason to $\Phi$ then acting for the reason that $\mathrm{P}$ is $\Phi$-ing for the reason that $\mathrm{P}$. Not acting for $\mathrm{P}$ is not $\Phi$-ing for the reason that P. (Raz 1979: 17)

If I understand him correctly, Raz takes $\Phi$-ing for the reason that $\mathrm{P}$ and intentionally refraining from $\Phi$-ing for the reason that $\mathrm{P}$ to be themselves actions, call them acts of $\Psi$-ing. We might thus call $\Psi$-ing a second-order action. $\Psi$-ing is the second-order action of $\Phi$-ing for a reason or refraining from $\Phi$-ing for a reason. Pre-emptive reasons are thus reasons for $\Psi$-ing, where to $\Psi$ is to refrain from $\Phi$-ing for certain conflicting first-order reasons.

By construing pre-emptive reasons in this way, Raz is in a position to claim, quite plausibly, that authoritative directives do not pre-empt subjects from considering or deliberating about the conflicting first-order reasons that the directive is meant to exclude. Subjects can deliberate all they want about such conflicting reasons. Authoritative directives are only meant to pre-empt subjects' acting on the excluded reasons. ${ }^{7}$

The fact that pre-emptive reasons are reasons for what I am calling second-order actions puts pressure on the idea that there can be preemptive reasons for belief. ${ }^{8}$ If there are pre-emptive reasons for belief, then presumably they are not second-order reasons for action. Instead, they must be second-order reasons for some kind of doxastic parallel to second-order actions. But is there such a parallel? Second-order actions are acts of acting or refraining from acting for reasons, but is there anything like a higher-order doxastic state that is itself an instance of believing for a reason or intentionally refraining from believing for a reason? I cannot see that there is. Of course, there are second-order beliefs in the sense of beliefs that have other beliefs as their content, but this isn't what we need. What we need is something that parallels a second-order action, an act of $\Psi$-ing, where to $\Psi$ is to $\Phi$ for a reason or intentionally refrain from $\Phi$-ing for a reason. Believing that $\mathrm{p}$ for a reason or refraining from believing that $\mathrm{p}$ for a reason is not itself an instance of a higher-order doxastic state. I thus don't see how there can be such a thing as a doxastic parallel to second-order actions.

\footnotetext{
${ }^{7}$ See especially the discussion in Raz (1989).

${ }^{8}$ For doubts about the notion of pre-emptive or exclusionary reasons for action see Gans (1986). While I am here assuming that we can make sense of the notion of secondorder reasons for action, I suspect that some of the considerations adduced here might be developed in such a way as to call into question the general category of second-order reasons.
} 
Here is another way of making the same point. Consider what a reason for believing for a reason or refraining from believing for a reason might be. Here it will be helpful to introduce some further non-Razian terminology. ${ }^{9}$ Let's take a reason to be a consideration that bears, not on an action or attitude, but on a question. A consideration that bears on the question whether to $\Phi$, where $\Phi$-ing is an action, is a practical reason, and a consideration that bears on the question whether $\mathrm{p}$, where $\mathrm{p}$ is a proposition, is an epistemic reason. Second-order reasons for action can thus be construed as considerations that bear on the question whether to act for a reason. Insofar as Raz construes acting for a reason as itself a kind of action, what I've called a second-order act of $\Psi$-ing, the question whether to act for a reason, whether to $\Psi$, can be construed as a question of the form whether to $\Phi$. But what are we to make of second-order reasons for belief? Second-order reasons for belief would be considerations that bear on the question whether to believe that $\mathrm{p}$ for a reason. But what is the form of the question whether to believe that $p$ for a reason? To believe that $\mathrm{p}$ for a reason is not a proposition. The question whether to believe that $\mathrm{p}$ for a reason thus is not a question of the form whether $\mathrm{p}$, and since it is not a question of the form whether $\mathrm{p}$, considerations that bear on this question cannot be epistemic reasons.

The concept of second-order reasons for belief thus looks to me to be incoherent. If there are such reasons, then presumably they are epistemic reasons, considerations that bear on a question of the form whether $\mathrm{p}^{10}$ But I cannot see how there can be, as it were, second-order questions of this form. Second-order reasons for action are considerations that bear on the question whether to $\Psi$, where to $\Psi$ is to $\Phi$ for a reason. Secondorder epistemic reasons would be considerations that bear on a question

${ }^{9} \mathrm{I}$ here draw on the conception of reasons and rational agency recently defended by Pamela Hieronymi. See especially Hieronymi (2005) and (2006).

${ }^{10}$ Perhaps second-order reasons for belief can be construed as practical reasons, as what are sometimes called 'pragmatic' reasons for belief. They would then be reasons for performing actions (including mental actions) designed to bring about believing for a reason or not believing for a reason. For example, a speaker's testimony that $\mathrm{p}$ might be construed as both a first-order epistemic reason for believing that $\mathrm{p}$ and a practical reason for acting in ways designed to, say, prevent one from failing to believe that $\mathrm{p}$ for certain other conflicting reasons. On such a construal, however, I don't think we have something that is aptly construed as a second-order reason. Instead, we have a consideration that is both a first-order epistemic reason and a first-order practical reason. This amounts to a serious departure from the official Razian account of authority. Moreover, while I cannot consider such a proposal in any detail here, I doubt that it will yield a plausible conception of the nature of epistemic authority. 
of the form whether $\mathrm{p}$, where $\mathrm{p}$ was itself something like believing for a reason. But believing for a reason isn't a proposition. I therefore tentatively conclude that, insofar as pre-emptive reasons for belief are supposed to be second-order epistemic reasons, there can be no preemptive reasons for belief.

Raz has a quite detailed conception of the nature of pre-emptive reasons. I have argued, pace Raz himself, that these details do not leave room for pre-emptive reasons for belief. Notably, however, Zagzebski does not discuss many of the details of the Razian conception of preemption, including the notion of second-order reasons that I have relied upon heavily here, so perhaps she has a slightly different conception of pre-emption in mind. I have said nothing about a non-Razian distinction that Zagzebski introduces between first-person or deliberative reasons and third-person or theoretical reasons, and there is at least one point at which Zagzebski suggests that this distinction is helpful for understanding the way in which pre-emption works (2012: 114). Perhaps the distinction between deliberative and theoretical reasons can be employed so as to develop an alternative account of pre-emption that will make room for pre-emptive reasons for belief. At this point, however, I do not see how exactly this would go.

\section{AUTHORITIES AND INSTRUMENTS}

Even if we can make sense of the notion of pre-emptive reasons for belief, however, I have a final worry. I admit that this worry is a bit amorphous, but it seems to me important. The philosophical problem of authority is often construed as the problem of how it can ever be morally or rationally justified to submit oneself to the will of another in the way that is characteristic of deference to authority. The general Razian strategy for addressing this problem, I take it, is to argue that, as long as certain conditions are met, conforming to the directives of authorities is an indirect way of conforming to the reasons for action that exist anyway. As Raz has recently put it:

In postulating that authorities are legitimate only if their directives enable their subjects to better conform to reason, we see authority for what it is: not a denial of people's capacity for rational action, but simply one device, one method, through the use of which people can achieve the goal (telos) of their capacity for rational action, albeit not through its direct use. (2009: 140) 
Similarly, Zagzebski argues that, while there might be occasions on which we value deciding for ourselves more than we value truth, believing on authority is an indirect means of attaining the epistemic ends of attaining truth and avoiding falsity. To the extent that we value getting the truth, we are often better off relying on epistemic authorities than we are trying to determine what to believe for ourselves. We thus have a straightforward defence of deference to epistemic authority as simply the most rational or epistemically conscientious thing to do.

While I think that this is all very plausible, I worry that it sidesteps the problem of authority rather than squarely addressing it. For many philosophers, the philosophical problem of authority is not simply a problem concerning whether deference to authority can be instrumentally justified. Instead, the problem seems to concern whether the notion of deference to epistemic or practical authority is even coherent. Just as an example, consider the way in which Herbert Marcuse frames the issue in the introduction to his A Study on Authority:

The authority relationship, as understood in these analyses, assumes two essential elements in the mental attitude of he who is subject to authority: a certain measure of freedom (voluntariness: recognition and affirmation of the bearer of authority, which is not based purely on coercion) and conversely, submission, the tying of will (indeed of thought and reason) to the authoritative will of an Other. Thus in the authority relationship freedom and unfreedom, autonomy and heteronomy, are yoked in the same concept and united in the single person of he who is subject. (2008: 7)

Marcuse here claims that there is a kind of paradox involved in the very concept of obedience or deference to authority. Authorities aim at a response from their subjects that is somehow simultaneously free and unfree, that involves freely willing to not will for oneself or freely judging to not judge for oneself. This sense of paradox in the notion of subjecting or submitting oneself to authority is something that gets washed out in both Raz and Zagzebski's accounts. Perhaps it is appropriately washed out. Perhaps there is nothing here but confusion. But it seems to me that there is something correct and important about what Marcuse, like many others, is gesturing at. ${ }^{11}$ The question is how to understand it.

${ }^{11}$ Similar sentiments are expressed by philosophical anarchists like Godwin (1971) and Wolff (1970) and by defenders of authority like Arendt (1954). 
On the general Razian view, I take it that the notion of pre-emption is supposed to capture whatever sense there is in the idea that deference to authority involves subjecting or submitting oneself to another. ${ }^{12} \mathrm{On}$ Zagzebski's epistemic version of this view, epistemic authorities provide reasons that replace my other reasons relevant to believing. In believing that $\mathrm{p}$ on the authority of someone else, I am subjecting myself to the judgment of the other in that I am believing that p pre-emptively. The problem, however, is that on both Raz and Zagzebski's accounts, it can look like pre-emption comes rather easily. A reason is pre-emptive just so long as it is one that excludes a belief or action being based on certain other conflicting reasons. In this respect, lots of considerations might amount to pre-emptive reasons. For Raz, not only authoritative directives but other kinds of mandatory rules, promises, and even decisions provide pre-emptive reasons. We've seen that one might be justified in treating a speaker's request or advice as a pre-emptive reason for action, and it seems that we might also be justified in treating things like the readings of ordinary instruments pre-emptively. At the end of Chapter 5, Zagzebski writes that her account of the authority of belief 'applies to inanimate objects like GPS systems, thermometers, and other instruments' (2012: 119). A thermometer might thus provide pre-emptive reasons for belief concerning the temperature in the room, and a car's GPS device might provide pre-emptive practical reasons for taking the next exit.

I doubt that Raz would be willing to count such instruments as authorities. If authority is construed as a normative power to give or generate for others pre-emptive reasons, and if normative powers are defined in roughly the way that Raz defines them, as requiring the performance of an intentional action, then it will look like only agents can be genuine authorities. ${ }^{13}$ Still, it isn't clear from Raz's account why exactly agency matters here. His defence of authority focuses on the way in which pre-emption is a means of maximizing conformity with reason, and this defence doesn't appeal to anything explicitly agential. The considerations that he claims provide pre-emptive reasons are intentional actions, but it isn't clear why they need be. In a way, this contributes to the strength of the Razian defence of authority. Authority looks no

12 See, for example, Raz's claim that the philosophical anarchist simply overlooks the possibility of the existence of second-order reasons (1979: 27).

${ }^{13}$ Perhaps instruments can be construed as having a kind of authority that is derived from the authority of their designers, but then it looks like we need a distinction between original and derived authority. 
more morally or rationally problematic than any other indirect means of securing conformity with reason, but at the same time, I worry that we've lost touch with what was supposed to be so distinctive, and distinctively worrying, about authority. The paradoxical nature of authority pointed to by writers like Marcuse seems fundamentally to do with the notion of freely submitting oneself to another agent.

Consider in this respect what distinguishes our reliance on instruments from our reliance on practical and epistemic authorities. In the case of instruments that provide reasons for action, like, for example, a car's GPS device, we are often justified in treating what the device indicates as a reason for action. We might even be justified in treating what the device indicates as a pre-emptive reason, as a reason that is not simply added to the balance of reasons but that actually excludes certain other conflicting reasons. Even if we treat what the device indicates pre-emptively, however, we are not obeying the device (though we might sometimes choose to talk in this way). We are not treating the device as we would another person whom we recognize as being in a position to settle for us the question what to do. We are not subjecting our wills to the device, and it is this subjection to others that renders authority both distinctive and distinctively problematic.

This suggests that the distinctiveness of authority cannot be explained in terms of pre-emption alone, in the way that Raz tends to explain it. If ordinary instruments can provide pre-emptive reasons, as Zagzebski suggests, and if in treating them pre-emptively we are not subjecting our wills to the instrument in the way that obedience to authority involves subjecting our will to the authority, then the distinctiveness of authoritative directives cannot consist in their pre-emptive nature alone.

This is a general worry about the sufficiency of the Razian account of authority, but it has a more specific application in the case of epistemic authority. I have suggested that the difference between the indications of a practical instrument like a car's GPS device and the directives of legitimate practical authorities is that the latter purport to settle practical questions for us, thereby subjecting us to their wills, in a way that the former do not. The notion of authorities settling questions for us is, of course, in need of further explanation, but I have suggested that preemption alone might be insufficient to explain it. If we turn to the case of epistemic authority, however, one might wonder whether this notion even applies. There is, I think, a pretty clear intuitive distinction between 
following the directions of a GPS device and obeying the directives of a legitimate practical authority, but one might wonder whether there is such a clear distinction between, for example, believing the readings of a thermometer and believing the testimony of a climate scientist. We might treat both pre-emptively, but does believing the testimony of the climate scientist really involve submitting ourselves to the scientist in a way that believing the readings of a thermometer does not? If not, then it isn't clear that testimony involves a kind of authority that robustly parallels practical authority.

Zagzebski seems to think that there is a genuine sense in which testimony, like authoritative practical directives, purports to settle theoretical questions for us in a way that involves our submitting ourselves to the authority. At the beginning of Chapter 6, she argues that the authority of testimony brings with it an interpersonal dimension that is lacking in the case of the authority of belief. The speech act of telling an audience that $\mathrm{p}$ differs from other speech acts that aim to influence the beliefs of others in that telling involves an assumption of responsibility on the part of the speaker for the conscientiousness of the audience's belief.

Telling is a two-way street. The teller asks for trust and counts on the recipient to trust her. In return, she assumes the responsibility that goes with that trust, taking upon herself the epistemic burden of believing in a conscientious fashion, and doing so not only for herself, but for the recipient. (Zagzebski 2012: 124)

In telling an audience that $\mathrm{p}$, a speaker aims for the audience to believe her that $\mathrm{p}$, to believe that $\mathrm{p}$ on the speaker's authority, where this involves the audience's ceding to the speaker at least partial responsibility for the conscientiousness of her belief. Perhaps something similar is true of practical authority. In telling an audience to $\Phi$, a speaker aims for the audience to obey her, where this involves the audience's ceding to the speaker at least partial responsibility for the appropriateness of her action, for her $\Phi$-ing being the thing to do in the situation. In this way, believing that $\mathrm{p}$ on the authority of a speaker might be construed as allowing the speaker to settle for one the question whether $\mathrm{p}$ in a way that parallels that in which obeying a speaker's command involves allowing the speaker to settle for one the question what to do. The notion of an authority's settling questions for others and thereby subjecting others to her will or judgment is here cashed out in terms of the responsibility 
that the authority assumes, and the subject cedes to the authority, for the conscientiousness of the audience's belief or action.

Such an account of the parallel between theoretical and practical authority has several virtues. First, it succeeds, I think, in distinguishing obedience or deference to authority from reliance on ordinary instruments. Responsibility for belief and action can only be distributed between beings capable of such, between agents. Even if we treat the readings of an instrument pre-emptively, we are not thereby ceding responsibility for our belief or action to the instrument. Second, and relatedly, this account appears to be in a better position than the general Razian position to make sense of the paradox of authority depicted in the passage from Marcuse. On the general Razian view, pre-emption is an indirect means of maximizing conformity to reason. On the alternative outlined here, however, authority has a distinctive impact on the agency of others. Authorities purport to take over for others the activity of settling theoretical and practical questions, and while this might very well have the effect of maximizing others' conformity to reasons, one might worry that taking over aspects of others' agential activity remains an affront to their status as rational agents. Third, this account of the parallel between epistemic and practical authority avoids the problem that I have raised concerning the application of the notion of pre-emption to the realm of belief. As far as I can see, there is nothing standing in the way of thinking that responsibility for belief (assuming, I think plausibly, that there is such a thing) can be distributed between authority and subject in a way that parallels that in which responsibility for action can be so distributed. As such, this account makes room for a robust parallel between epistemic and practical authority.

Zagzebski's claims concerning the interpersonal dimension of the authority of testimony do not help to solve the problem that I have raised concerning the authority of belief. It is hard to see how either the case of my neighbour or Zagzebski's case of the pedestrians involve the interpersonal ceding and accepting of responsibility involved in an authority's settling for another a theoretical question. Nevertheless, I think that they do go some distance towards solving the other two problems that I have raised. They do so, however, only by going beyond the official Razian framework for understanding authority. They are consistent with the idea that authority is, at least in part, a normative power to give pre-emptive reasons, but the appeal to pre-emption doesn't itself explain these interpersonal features. If this is right, then 
the interpersonal dimension of authority might be something that needs to feature more centrally in our understanding of both epistemic and practical authority.

\section{BIBLIOGRAPHY}

Arendt, Hannah. 1954. 'What is Authority?' in Between Past and Future (New York: The Viking Press)

Gans, Chaim. 1986. 'Mandatory Norms and Exclusionary Reasons', Philosophy, 15: 373-394

Godwin, William. 1971. Enquiry Concerning Political Justice (Oxford: Clarendon Press)

Hieronymi, Pamela. 2005. 'The Wrong Kind of Reason', The Journal of Philosophy, 102: 437-457

Hieronymi, Pamela. 2006. 'Controlling Attitudes', Pacific Philosophical Quarterly, 87: $45-74$

Lawlor, Krista. 2013. Assurance: An Austinian View of Knowledge and Knowledge Claims (Oxford: Oxford University Press)

Marcuse, Herbert. 1972. A Study on Authority (New York: Verso)

McMyler, Benjamin. 2011. Testimony, Trust, and Authority (New York: Oxford University Press)

Raz, Joseph. 2009. 'The Problem of Authority: Revisiting the Service Conception', in Between Authority and Interpretation (New York: Oxford University Press)

Raz, Joseph. 1999. Practical Reason and Norms (New York: Oxford University Press)

Raz, Joseph. 1989. 'Facing Up: A Reply', Southern California Law Review, 62: 1153-1235

Raz, Joseph. 1986. The Morality of Freedom (New York: Oxford University Press) Raz, Joseph. 1979. The Authority of Law (New York: Oxford University Press)

Wolff, Robert Paul. 1970. In Defense of Anarchism (Berkeley: University of California Press)

Zagzebski, Linda Trinkaus. 2012. Epistemic Authority: A Theory of Trust, Authority, and Autonomy in Belief (New York: Oxford University Press) 